First Peoples Child \& Family Review

An Interdisciplinary Journal Honouring the Voices, Perspectives, and Knowledges of First Peoples through Research, Critical Analyses, Stories, Standpoints and Media

Reviews

\title{
Foreword
}

\section{Tara Hanson}

Volume 5, Number 2, 2010

URI: https://id.erudit.org/iderudit/1068925ar

DOI: https://doi.org/10.7202/1068925ar

See table of contents

Publisher(s)

First Nations Child and Family Caring Society of Canada

ISSN

1708-489X (print)

2293-6610 (digital)

Explore this journal

Cite this document

Hanson, T. (2010). Foreword. First Peoples Child \& Family Review, 5(2), 4-4.

https://doi.org/10.7202/1068925ar viewed online.

https://apropos.erudit.org/en/users/policy-on-use/ 


\section{First Peoples Child \& Family Review}

An Interdisciplinary Journal Honoring the Voices, Perspectives and Knowledges of First Peoples through Research, Critical Analyses, Stories, Standpoints and Media Reviews

Volume 5, Number 2, 2010, p.4

\section{Foreword}

\section{Tara Hanson}

Director of Knowledge and Partnership Development, The Alberta Centre for Child, Family and Community Research

This issue of The Review is published in partnership between The First Nations Child and Family Caring Society of Canada and The Alberta Centre for Child, Family and Community Research (The Centre). With endorsement from our Aboriginal Advisory Committee Co-Chairs, Dr. Jean Lafrance and Bernadette Iahtail, The Centre is pleased to sponsor the final 2010 and upcoming 2011 issues of The First Peoples Child \& Family Review.

The Centre is a not-for-profit, charitable organization that is primarily funded by the Alberta Ministry of Children and Youth Services and operates arms-length from government.

Our mission is to collaboratively develop, support and integrate evidence across sectors and disciplines to provide a strong foundation for identifying and promoting effective public policy and service delivery to improve the well-being of children, families, and communities.

Under the direction and guidance provided by our Aboriginal Advisory Committee, The Centre's strategic approach is to support and increase the capacity of Aboriginal communities to identify and implement solutions in a manner that aligns with their values and culture.

We support community-based research that builds on and respects existing strengths, local skills, values, wisdom and culture. There is much to be learned by blending research approaches with traditional wisdom and different ways of knowing as exemplified in the articles that appear in this issue of First Peoples Child \& Family Review.
We look forward to our collaboration with The First Nations Child and Family Caring Society of Canada to mobilizing knowledge and evidence through The First Peoples Child \& Family Review to promote child welfare research, practice, policy and education and to advance innovative approaches within the field of Aboriginal/First Peoples child welfare.

We welcome you to visit our site for further information about The Centre at www.research4children.com.

Tara Hanson, Director of Knowledge and Partnership Development The Alberta Centre for Child, Family and Community Research

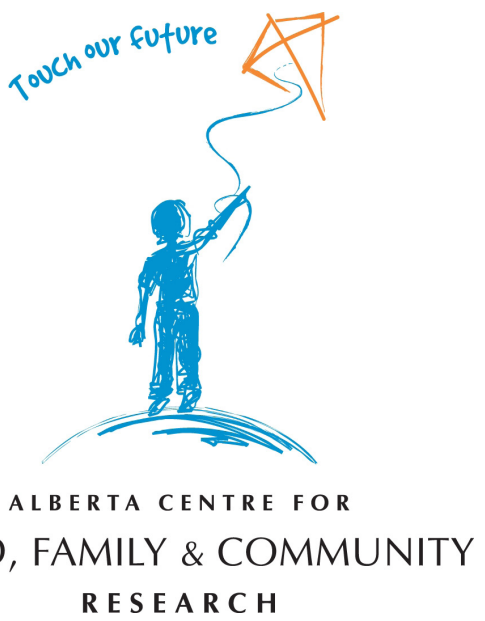

